\title{
Vesicle-independent extracellular release of a proinflammatory outer membrane lipoprotein in free-soluble form Maribasappa Karched ${ }^{1}$, Riikka Ihalin ${ }^{1,4}$, Kjell Eneslätt ${ }^{1}$, Deyu Zhong 1,5, Jan Oscarsson ${ }^{1}$, Sun N Wai ${ }^{2}$, Casey Chen ${ }^{3}$ and Sirkka E Asikainen*1
}

\begin{abstract}
Address: ${ }^{1}$ Oral Microbiology, Department of Odontology, Umeå University, SE-90187 Umeå, Sweden, ${ }^{2}$ Department of Molecular Biology, Umeå University, SE-90187 Umeå, Sweden, ${ }^{3}$ Primary Oral Health Care, USC School of Dentistry, University of Southern California, 925 W. 34 th Street, Los Angeles CA 90089-0641, USA, ${ }^{4}$ Department of Biochemistry and Food Chemistry, University of Turku, Turku FIN-20520, Finland and ${ }^{5}$ Department of Dentistry, Medical School Hospital of Qingdao University, Qingdao, People's Republic of China

Email: Maribasappa Karched - maribasappa.karched@odont.umu.se; Riikka Ihalin - riikka.ihalin@utu.fi; Kjell Eneslätt - kjell.eneslatt@odont.umu.se; Deyu Zhong - qdzdy369@yahoo.com.cn; Jan Oscarsson - jan.oscarsson@odont.umu.se; Sun N Wai - Sun.Nyunt.Wai@molbiol.umu.se; Casey Chen - ccchen@usc.edu; Sirkka E Asikainen* - sirkka.asikainen@odont.umu.se

* Corresponding author
\end{abstract}

Published: 28 January 2008

BMC Microbiology 2008, 8:18 doi:10.1 I86/147|-2180-8-18
Received: 2 July 2007

Accepted: 28 january 2008

This article is available from: http://www.biomedcentral.com/I47I-2/80/8//8

(c) 2008 Karched et al; licensee BioMed Central Ltd.

This is an Open Access article distributed under the terms of the Creative Commons Attribution License (http://creativecommons.org/licenses/by/2.0), which permits unrestricted use, distribution, and reproduction in any medium, provided the original work is properly cited.

\begin{abstract}
Background: Aggregatibacter actinomycetemcomitans is an oral bacterium associated with aggressively progressing periodontitis. Extracellular release of bacterial outer membrane proteins has been suggested to mainly occur via outer membrane vesicles. This study investigated the presence and conservation of peptidoglycan-associated lipoprotein (AaPAL) among $A$. actinomycetemcomitans strains, the immunostimulatory effect of AaPAL, and whether live cells release this structural outer membrane lipoprotein in free-soluble form independent of vesicles.

Results: The pal locus and its gene product were confirmed in clinical A. actinomycetemcomitans strains by PCR-restriction fragment length polymorphism and immunoblotting. Culturing under different growth conditions revealed no apparent requirement for the AaPAL expression. Inactivation of pal in a wild-type strain (D7S) and in its spontaneous laboratory variant (D7SS) resulted in pleiotropic cellular effects. In a cell culture insert model (filter pore size $0.02 \mu \mathrm{m}$ ), AaPAL was detected from filtrates when strains D7S and D7SS were incubated in serum or broth in the inserts. Electron microscopy showed that $A$. actinomycetemcomitans vesicles $(0.05-0.2 \mu \mathrm{m})$ were larger than the filter pores and that there were no vesicles in the filtrates. The filtrates were immunoblot negative for a cytoplasmic marker, cyclic AMP (cAMP) receptor protein. An ex vivo model indicated cytokine production from human whole blood stimulated by AaPAL.
\end{abstract}

Conclusion: Free-soluble AaPAL can be extracellularly released in a process independent of vesicles.

\section{Background}

Aggregatibacter actinomycetemcomitans [1] is a small Gramnegative rod implicated in aggressive forms of periodontitis [2]. We recently identified and characterized in A. actin- omycetemcomitans a $17-\mathrm{kDa}$ peptidoglycan-associated lipoprotein (PAL) $[3,4]$, which is a widely conserved outer membrane lipoprotein (OMLP) among Gram-negative bacteria [5]. The PALs of several pathogens, such as Hae- 
mophilus influenzae, Escherichia coli [6-9], Legionella pneumophila, Bordetella pertussis, and Campylobacter jejuni [1012] are proinflammatory and/or strongly immunogenic and can contribute to serum resistance of the bacterium [13]. PAL may be an important bacterial mediator in sepsis caused by Gram-negative bacteria [7] and is crucial for full expression of virulence of Haemophilus ducreyi [14].

Extracellular release of bacterial virulence factors is a principal mechanism of bacterial pathogenicity [15]. Different strategies of release include specialized secretory systems [15-17], outer membrane vesicles $[18,19]$, and autolysis [20]. Release of outer membrane vesicles is regarded as the primary mechanism for delivering structural surface components, such as outer membrane proteins (OMP) and lipopolysaccharide (LPS), into the extracellular milieu. Most previous studies on the released bacterial outer membrane components, however, have focused on detecting and isolating them from serum or culture supernatants, or on testing their biological activity [21-25]. Less attention has been directed to elucidating whether these components in the test material were derived from lysed cells, outer membrane vesicles, and/or were released from live bacteria in free-soluble form. Importantly, the bacterial cell components that are released in free-soluble form may be biologically more active than their membranebound counterparts associated with intact bacterial cells or outer membrane vesicles [26].

The present study was designed to investigate the presence and conservation of PAL among clinical A. actinomycetemcomitans strains and whether live A. actinomycetemcomitans cells release PAL (AaPAL) in free-soluble form. To accomplish these objectives, inserts with $0.02-\mu \mathrm{m}$ pore-size filter were used to separate bacterial cells from cell culture wells containing serum or broth. We present compelling evidence for the release of AaPAL in free-soluble form by demonstrating presence of AaPAL in the filtrates obtained after incubation, by monitoring bacterial viability in the insert, and by checking for the absence of cell lysis and outer membrane vesicles in the filtrate. Proinflammatory effect of AaPAL was shown in an ex vivo model using human whole blood.

\section{Results}

The pal gene was conserved and the protein expressed in clonally diverse A. actinomycetemcomitans strains

A total of $33 \mathrm{~A}$. actinomycetemcomitans strains were analyzed by PCR and immunoblotting. The results from 12 strains representing 6 serotypes and 9 genotypes are shown (Fig. 1). The genomic DNA and the whole cell protein preparation of these strains each produced the expected 425-bp amplicon in PCR and the 17-kDa immunoblot signal with anti-AaPAL peptide antiserum, respectively.

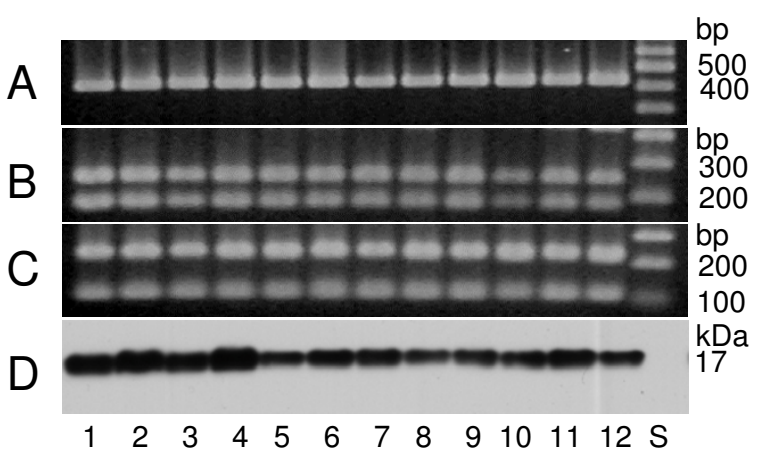

\section{Figure I}

PCR-RFLP of pal and detection of its gene product, PAL, from clonally diverse $A$. actinomycetemcomitans strains. Panel A: Agarose gel electrophoresis of the PCR products shows amplicons with the expected size of pal (425 bp) for each strain. Panels B and C: Agarose gel electrophoresis of the purified PCR amplicons digested with Ddel and BspMI, separately. Panel D: immunoblot analysis of the A. actinomycetemcomitans whole cell protein preparations using anti-AaPAL peptide antiserum shows the expected $17-\mathrm{kDa}$ signal for each strain. Lanes I through 12 strain identification (serotype; genotype): ATCC 29523 (a; I), SA5002 (a; I), ATCC 43718 (b; 2), SA5003 (b; 8), ATCC 33384 (c; 3), SA5005 (c; 3), SA500I (d; 5), SA5007 (d; 22), SA5008 (e; 6), SA50II (e; 20), CUI000R (f; nd*), SA5022 (f; 19) and standards (S). *nd: not determined.

The RFLP analysis with two enzymes, DdeI and BspMI, cutting once within the pal sequence [4] showed that the restriction patterns were similar among all test strains (Fig. 1). The DdeI-digested fragments were 175 and 250 $\mathrm{bp}$, as predicted, whereas the BspMI-digested fragments were 100 and $225 \mathrm{bp}$, which were not the predicted sizes of 324 and $101 \mathrm{bp}$, respectively. The reason seems to be a recognition site for BspMI on the opposite strand approximately $100 \mathrm{bp}$ away from the reverse primer binding sequence.

\section{AaPAL was expressed in various culture conditions}

To determine the environmental requirements for AaPAL expression, we cultured A. actinomycetemcomitans strains in different nutritional and atmospheric conditions. Besides conventional cultures, strains were also grown as biofilm [27]. The immunoblot analyses of the whole cell protein preparations of strains D7S and D7SS, but not D7SS-p, revealed 17-kDa signals, regardless of the culture conditions (Fig. 2). Furthermore, the $17-\mathrm{kDa}$ band appeared stronger when strains D7S and D7SS had been grown in broth incubated in $\mathrm{CO}_{2}$-supplemented (5\%) air than when grown in other conditions. A particularly 


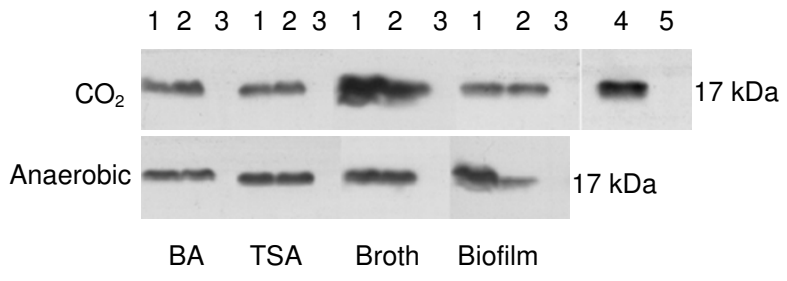

Figure 2

AaPAL expression in different growth conditions of A. actinomycetemcomitans. Strains D7S (wild-type, lane I), D7SS (spontaneous smooth-colony variant of D7S, lane 2), and D7SS-p (pal-deficient mutant of D7SS, lane 3) were cultured in various nutritional and atmospheric conditions (for details, see Materials and Methods). Bacterial whole cell protein preparations ( $10 \mu \mathrm{g} /$ well) were subjected to immunoblot analysis with anti-AaPAL peptide antiserum. The OMP preparations from the strains D7SS (lane 4) and D7SS-p (lane 5) were used as a positive and a negative control, respectively. $\mathrm{CO}_{2}: \mathrm{CO}_{2}$-enriched air (5\%); BA: blood agar; TSA: trypticase soy agar.

strong band was also seen for strain D7S grown as biofilm under anaerobic incubation.

\section{Phenotype of the pal-deficient mutants}

The strain D7SS-p was constructed to be used as a negative control in the experiments. The strain D7S-p was also constructed to serve as a negative control, but particularly in the experiments aimed to demonstrate with a clinical strain, D7S, that AaPAL release was not restricted to its spontaneous laboratory variant, D7SS.

Comparison between the phenotypes of the mutants and their parents (data for D7SS and D7SS-p are shown in Fig. 3 ) showed no distinct differences in the colony sizes or densities when standardized numbers of cells $\left(1 \times 10^{3}\right)$ were cultured on plates. The mutants, however, exhibited filamentous cell morphology when observed by wet mounting (phase contrast microscopy) and SEM. The altered cell morphology was more pronounced when bacteria were cultured in nutritionally poor (TSA) rather than in rich (supplemented blood agar) medium (data not shown). As judged from the SEM analysis, there was enhanced vesicle production by the strain D7SS-p relative to D7SS (Fig. 3Ae and 3f). Furthermore, the growth rate of the mutant appeared inferior to the parent (Fig. 3B). The antibiotic susceptibility comparison between the strains showed that for the mutant, the inhibition zone was larger $(\mathrm{P}<0.05)$ for erythromycin but not for cefotaxime or penicillin (Fig. 3C).

\section{AaPAL was detected in serum and broth filtrates}

To elucidate how AaPAL could be presented to the host during A. actinomycetemcomitans infection, we studied whether A. actinomycetemcomitans cells released AaPAL into extracellular space in free-soluble form. For this purpose, we designed an in vitro model, where standardized numbers of bacterial cells were exposed for up to $8 \mathrm{~h}$ to heat-inactivated FCS (Fig. 4A). To explore the possibility of AaPAL release during A. actinomycetemcomitans growth, another similar experiment using D7SS and D7SS-p was performed using culture broth and a longer incubation time (24 h) (Fig. 4B). Immunoblot analysis of the filtrates outside the inserts containing strain D7SS or D7S revealed an accumulation of AaPAL over time (data for D7SS and D7SS-p are shown in Fig. 4). No AaPAL was detected in the above experiments at any time point in the filtrate when either D7SS-p or D7S-p or No bacteria were incubated in the insert. In all of the above described serum and broth experiments, OMP preparations of strains D7SS and D7SS-p were used as positive and negative controls, respectively, in the immunoblot assays (data not shown).

Densitometric quantification indicated that for strain D7SS incubated in serum, AaPAL concentration after the first $2 \mathrm{~h}$ was $637 \mathrm{ng} / \mathrm{ml}$ and at $8 \mathrm{~h}$ was $932 \mathrm{ng} / \mathrm{ml}$ (a 1.5fold increase from $2 \mathrm{~h}$ ). Similarly, for strain D7S incubated in serum, AaPAL concentration after the first $2 \mathrm{~h}$ was $437 \mathrm{ng} / \mathrm{ml}$ and at $8 \mathrm{~h}$ was $750 \mathrm{ng} / \mathrm{ml}$ (a 1.7-fold increase from $2 \mathrm{~h}$ ). For strain D7SS in broth, AaPAL concentration at $24 \mathrm{~h}$ was $194 \mathrm{ng} / \mathrm{ml}$ (for strain D7S, only serum incubation was performed).

To ensure the viability of the bacteria during the AaPAL release experiments described above, we employed bacterial viable counts for samples taken from serum and broth inside the inserts at the same time points as samples that were taken from filtrates for the immunoblot analyses (data for D7SS and D7SS-p are presented in Fig. 4C). In serum, the mean CFU (per ml) counts of D7SS were 1.1fold higher at $2 \mathrm{~h}$ than at $0 \mathrm{~h}$ and 46.0 -fold higher at $8 \mathrm{~h}$ than at $2 \mathrm{~h}$. Similarly, the mean CFU counts of D7SS-p were 1.3-fold higher at $2 \mathrm{~h}$ than at $0 \mathrm{~h}$ and 30.0-fold higher at $8 \mathrm{~h}$ than at $2 \mathrm{~h}$.

In broth, the mean CFU counts of D7SS were 34.3-fold higher at 24-h than at $0 \mathrm{~h}$. In contrast, the CFU counts of D7SS-p were 62.2-fold lower at $24 \mathrm{~h}$ than at $0 \mathrm{~h}$ (Fig. 4C).

Since the AaPAL release experiment was performed for strains D7S and D7S-p in serum only, the viable count data are given here: The mean CFU counts of D7S were at 0 h $6.2 \times 10^{8}$, at 2 h $8.7 \times 10^{8}$ (a 1.4-fold increase), and at $8 \mathrm{~h} 1.16 \times 10^{10}$ (a 13.3-fold increase from $2 \mathrm{~h}$ ). The respective mean CFU counts for D7S-p were at $0 \mathrm{~h} 6.1 \times 10^{8}$, at 
A
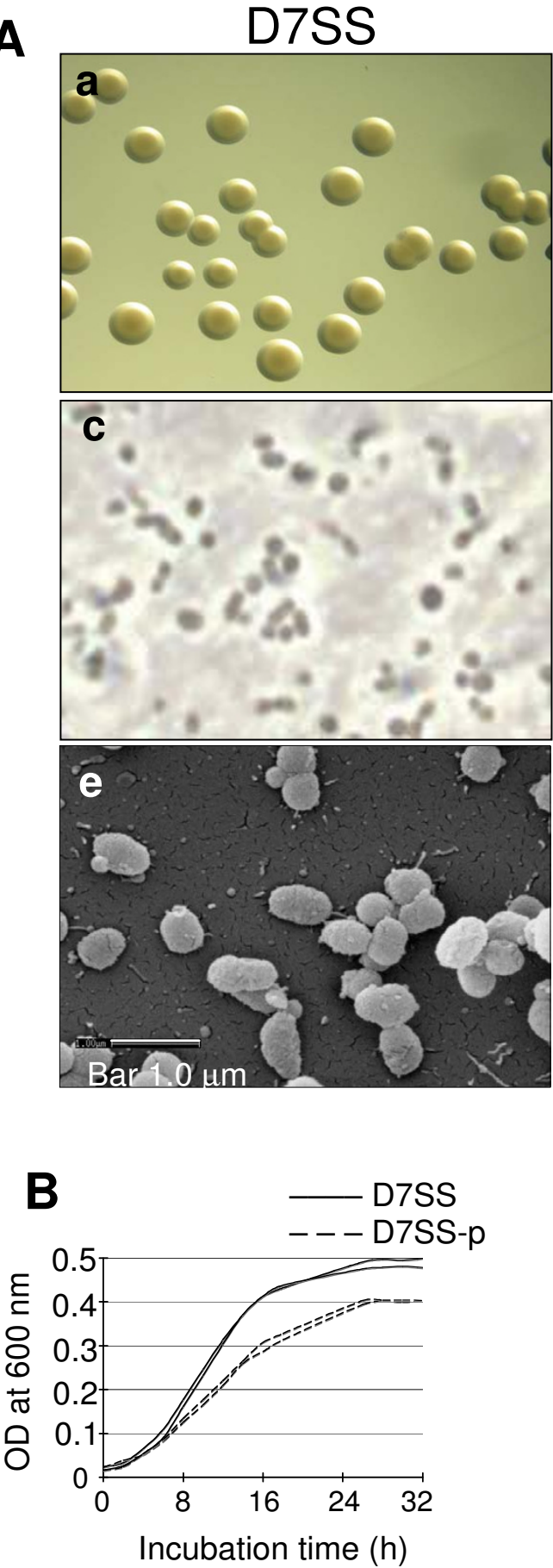

D7SS-p
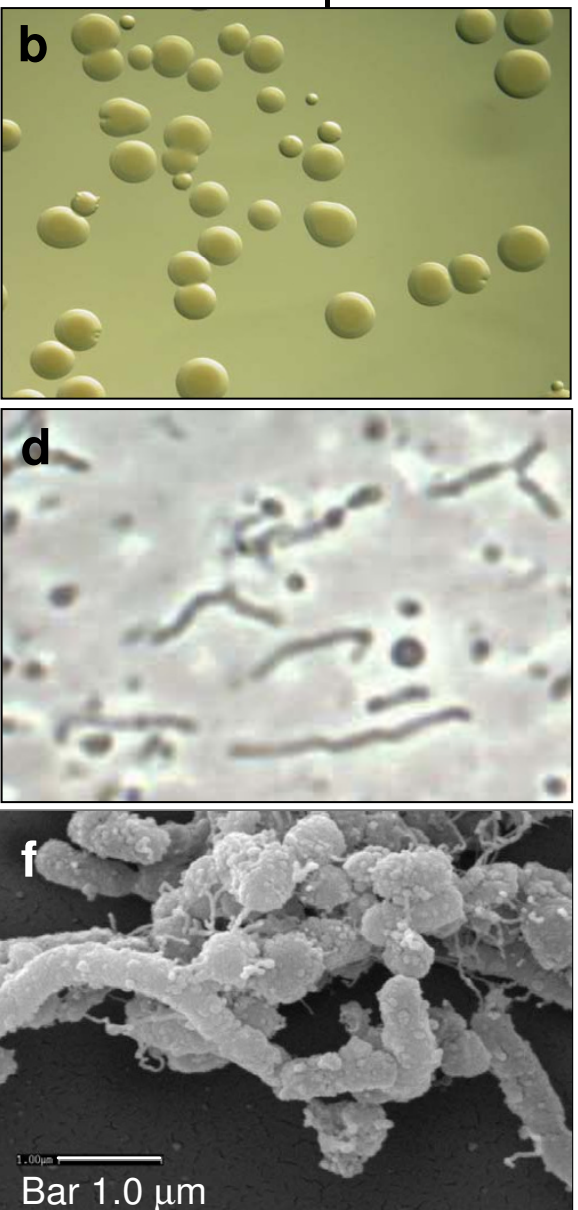

C

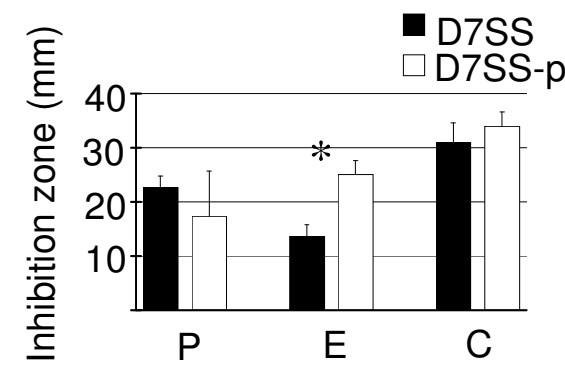

Figure 3

Role of AaPAL in cell physiology and membrane integrity. Panel A: Colony density and morphology $(a, b)$ and the cell morphology of A. actinomycetemcomitans strains D7SS and D7SS-p grown on TSA as examined by phase contrast microscopy (c, d) and scanning electron microscopy (e, f). Panel B: Growth rates of D7SS and D7SS-p in TSB measured by turbidimetry (OD 60 ). The results are shown from two separate experiments. Panel C: Antibiotic susceptibility comparison between the strains D7SS and D7SS-p. The results are means (SD) from three independent experiments $(* P<0.05)$. P, penicillin; E, erythromycin; C, cefotaxime. 

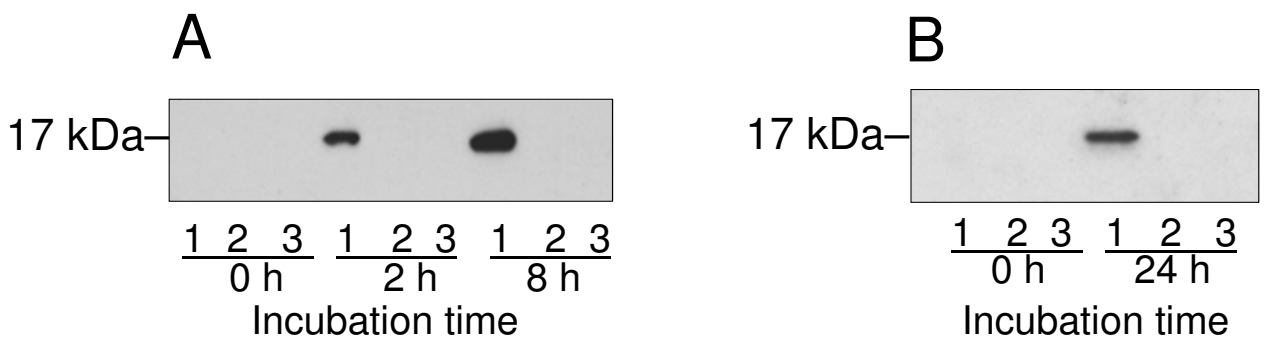

\begin{tabular}{|c|c|c|}
\hline \multicolumn{3}{|c|}{ Mean (SD) CFU/ml } \\
\hline Incubation time & D7SS & D7SS-p \\
\hline $\begin{aligned} & \text { Serum } \\
& \mathrm{h} \\
& 2 \mathrm{~h} \\
& 8 \mathrm{~h}\end{aligned}$ & $\begin{array}{l}1.3 \times 10^{10}\left(9.6 \times 10^{9}\right) \\
1.4 \times 10^{10}\left(8.9 \times 10^{9}\right) \\
6.3 \times 10^{11}\left(5.5 \times 10^{11}\right)\end{array}$ & $\begin{array}{l}6.8 \times 10^{9}\left(5.8 \times 10^{7}\right) \\
9.3 \times 10^{9}\left(7.4 \times 10^{9}\right) \\
2.8 \times 10^{11}\left(4.7 \times 10^{11}\right)\end{array}$ \\
\hline $\begin{array}{ll}\text { Broth } & \\
& 0 \mathrm{~h} \\
24 \mathrm{~h}\end{array}$ & $\begin{array}{l}2.4 \times 10^{7}\left(3.5 \times 10^{6}\right) \\
8.2 \times 10^{8}\left(9.6 \times 10^{8}\right)\end{array}$ & $\begin{array}{l}1.9 \times 10^{7}\left(7.2 \times 10^{6}\right) \\
3.0 \times 10^{5 *}\end{array}$ \\
\hline
\end{tabular}

*Data from one experiment is presented as no D7SS-p colonies were detected after $24 \mathrm{~h}$ in the other two experiments.

\section{Figure 4}

Immunoblot detection of PAL release from A. actinomycetemcomitans cells exposed to heat-inactivated FCS or cultured in broth. The samples were obtained from cell-culture wells outside the inserts, where the bacteria [D7SS (lane I) and D7SS-P (lane 2)] or No bacteria (lane 3) were incubated in serum for $2 \mathrm{~h}$ and $8 \mathrm{~h}$ (Panel A) or cultured in broth for $24 \mathrm{~h}$ (Panel B). AaPAL was detected by immunoblot using anti-AaPAL peptide antiserum. Samples for bacterial culture and enumeration were taken from the inserts containing serum or broth (Panel $C$ ) at the same time points as the samples for the immunoblots in Panels $A$ and $B$. The results show means (SD) from three independent experiments.

$2 \mathrm{~h} 9.5 \times 10^{8}$ (a 1.5-fold increase), and at $8 \mathrm{~h} 1.4 \times 10^{10}(\mathrm{a}$ 15.0-fold increase from $2 \mathrm{~h}$ ).

No bacterial growth was found in the samples from the serum or broth filtrates at any time point, ensuring that bacteria growing within the inserts had not passed through the filter and/or that the filtrates had not been contaminated.

For D7SS incubated in serum, although the mean LPS concentrations of the filtrates decreased 1.1-fold from $0 \mathrm{~h}$ to $2 \mathrm{~h}$, there was an increase of 1.7 -fold from $2 \mathrm{~h}$ to $8 \mathrm{~h}$. The mean LPS concentrations for strain D7SS-p incubated in serum increased 1.0-fold from $0 \mathrm{~h}$ to $2 \mathrm{~h}$ and 2.6-fold from $2 \mathrm{~h}$ to $8 \mathrm{~h}$ (Fig. 5). During broth culture, the mean LPS concentrations for D7SS and D7SS-p increased 2.5and 9.8-fold, respectively, from $0 \mathrm{~h}$ to $24 \mathrm{~h}$. However, there were no statistically significant differences in the amounts of LPS in the serum or broth filtrates between the two strains at any time point or in regard to the No bacteria control between the different time points. At the 0 time point, the LPS concentrations of D7SS and D7SS-p in both serum and broth filtrates were almost equal to those of the respective No bacteria control samples (Fig. 5).

We also tested for the release of additional A. actinomycetemcomitans components, apart from PAL and LPS, in the filtrates. Immunoblot analysis of the filtrates after an 8-h 

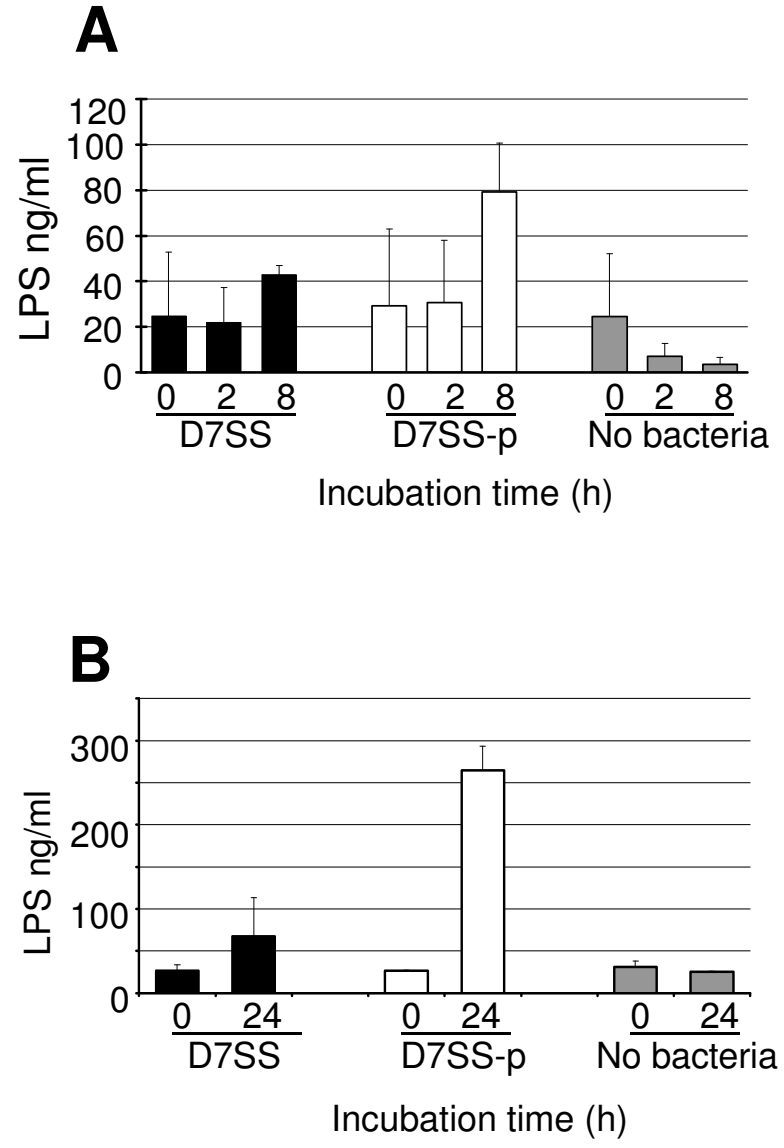

Figure 5

LPS released by A. actinomycetemcomitans cells using a cell culture insert model. Filtrates from serum incubation at 0,2 , and $8 \mathrm{~h}$ (Panel A) and broth culture at 0 and $24 \mathrm{~h}$ (Panel B) were subjected to quantification of LPS by Limulus assay. The results are means (SD) from two independent experiments.

serum incubation of D7SS, D7SS-p, and No bacteria was carried out by using an antiserum raised against whole cell antigen of $A$. actinomycetemcomitans serotype a (both D7SS and D7SS-p are of serotype a). Several immunoreactive bands of unknown identity but representing apparent molecular weights $\approx 10-120 \mathrm{kDa}$ were detected in the filtrates from both D7SS and D7SS-p, but not in the No bacteria controls (data not shown).

\section{Extracellular release of AaPAL was independent of cell lysis}

To exclude the possibility that the A. actinomycetemcomitans cells had lysed in the inserts, the filtrates in which AaPAL was detected were also tested by immunoblotting using specific antibodies against a cytoplasmic marker, cAMP receptor protein. Anti-Vibrio cholerae cAMP receptor protein antibodies were chosen since the protein is $79 \%$ identical and $94 \%$ similar to A. actinomycetemcomitans cAMP receptor protein. Whole cell protein preparation of $V$. cholerae $\left(c r p^{+}\right)$reacted at an expected $23 \mathrm{kDa}$ size, whereas A. actinomycetemcomitans whole cell protein preparation showed an immunoreactive band at $\approx 27 \mathrm{kDa}$ (Fig. $6)$. This molecular weight was higher than the weight deduced from its amino acid sequence, $24.2 \mathrm{kDa}$ (Oralgen; Oral Pathogen Sequence Database).

Our findings demonstrate that cAMP receptor protein could not be detected in any of the filtrate samples obtained from the cell-culture insert model (Fig. 6), not even when the filtrates were concentrated with trichloroacetic acid precipitation (data not shown).

To show that soluble cAMP receptor protein could be detected in filtrates from lysed bacteria, deliberately broken (See Methods) A. actinomycetemcomitans cells were incubated in cell culture inserts containing broth for $8 \mathrm{~h}$ as described above. As shown in Fig. 6, filtrates from lysed but not from unlysed D7SS cells contained detectable amounts of cAMP receptor protein.

\section{AaPAL was associated with A. actinomycetemcomitans outer membrane vesicles}

To investigate whether AaPAL could be detected in association with the vesicles, the vesicle preparations were analyzed using immunoblotting. A weak $17-\mathrm{kDa}$ signal was detected in D7SS but not D7SS-p vesicles (Fig. 7), whereas the vesicle preparation supernatants obtained after ultracentrifugation (containing soluble bacterial components), showed a strong AaPAL signal for strain D7SS (D7SS-p was negative) (Fig. 7).

\section{Extracellular release of AaPAL was independent of outer membrane vesicles}

Since AaPAL was detected in vesicle preparations from $A$. actinomycetemcomitans cultures (Fig. 7), we wanted to exclude the possibility that vesicles were the source of AaPAL in the filtrates. Electron microscopic examination of the vesicle preparations of the filtrates demonstrated large amounts of serum protein aggregates in all filtrates (Fig. 8). However, no vesicles were found in any of the filtrates at any time point. Data from time point $8 \mathrm{~h}$ are shown in Fig. 8. Vesicle preparations from D7SS whole cell suspension, used as a positive control, revealed vesicles of an average diameter 0.05-0.2 $\mu \mathrm{m}$ (Fig. 8).

\section{AaPAL induced cytokines in an ex vivo model}

The effect of AaPAL on the cytokine milieu in human whole blood was profiled by using a cytokine antibody array and a preparation of affinity purified AaPAL, containing less than $5 \mathrm{pg}$ LPS per $\mu$ g of AaPAL [3]. Production of interleukins IL- 6 and IL- 8 , and a macrophage inflam- 


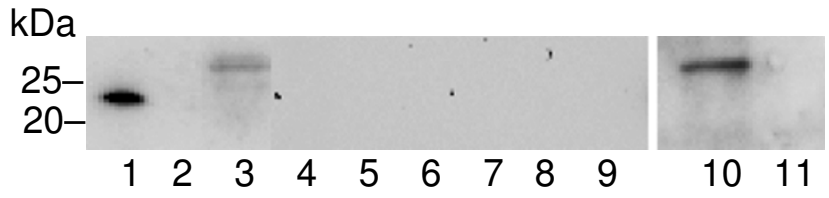

Figure 6

Immunoblot analysis of the filtrates for the detection of a cytoplasmic marker, cAMP receptor protein. The whole cell protein preparations of $V$. cholerae $\mathrm{crp}^{+}$strain (lane I), V. cholerae crp- strain (lane 2 ) and A. actinomycetemcomitans D7SS (lane 3) were used as controls in the immunoblot with antibodies against $V$. cholerae cAMP receptor protein. Serum filtrates (8 h): D7SS (lane 4), D7SS-p (lane 5) and No bacteria control (lane 6). Broth filtrates (24 h): D7SS (lane 7), D7SS-p (lane 8 ) and No bacteria control (lane 9). Detection of CAMP receptor protein from precipitated filtrates of lysed (lane 10) and unlysed D7SS cells (lane II) incubated in the inserts containing broth for $8 \mathrm{~h}$.

matory protein, MIP-1 $\beta$, was demonstrated by enhanced signals (Fig. 9). Based on visual analysis the effects appeared to be concentration-dependent.

\section{Discussion}

The present study demonstrates that $A$. actinomycetemcomitans releases AaPAL, a structural OMLP, in free-soluble form. The primary route for outer membrane components of bacteria, such as LPS and various proteins including porins $[18,19,28,29]$ to the extracellular space is through the release of outer membrane vesicles. Although not widely studied, there are a few reports on the release of OMPs, such as OmpA, PAL, and major lipoprotein (Braun's lipoprotein), either in soluble form [21,25,30] or

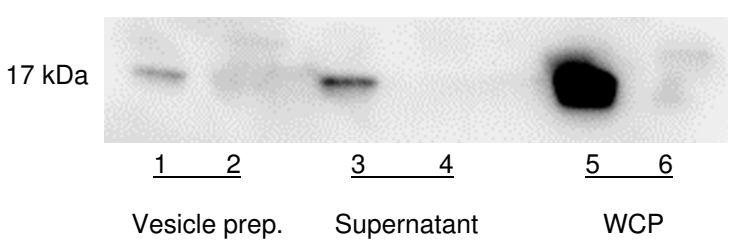

\section{Figure 7}

Immunoblot analysis of the vesicle preparations from A. actinomycetemcomitans strains D7SS and D7SS-p. The samples (5 $\mu \mathrm{g}$ protein each) were subjected to immunoblot analysis using anti-AaPAL peptide antiserum (I:500). The chemiluminescence signal was captured using a CCD camera integrated in ChemiDoc ${ }^{\mathrm{TM}}$ XRS gel documentation system (Bio-Rad). The images captured by the camera were acquired and imported to the attached computer using QuantityOne ${ }^{\circledR}$ software (Bio-Rad). Lanes: D7SS (lanes I, 3, 5) and D7SS-P (lanes 2, 4, 6). WCP; whole cell protein. in the form of complexes [23,31]. In those studies, however, the methods were not designed to exclude the presence of vesicles in the samples [25,31,32] or bacterial death or lysis $[21,25,30-32]$. Our study made an attempt to control those factors and showed that AaPAL is released independent of vesicles. Release of free-soluble bacterial components, such as shown here for a lipoprotein, would be of biological significance, since these components can cross anatomical barriers impermeable to whole bacteria or even vesicles [33-35]. In addition, there is evidence to suggest that in free form bacterial components convey higher biological activity than when they are membranebound in intact bacteria or in vesicles [26]. Regardless, the results of the present study accentuate a less studied strategy by which oral bacteria, like bacteria in other localized infections, may express extended pathogenicity.

Our experimental model comprised a cell culture insert. Based on the previous literature on A. actinomycetemcomitans outer membrane vesicles [36], we chose a membrane filter with a pore size $(0.02 \mu \mathrm{m})$ that would not allow cells or vesicles to pass through. An electron microscopic examination verified that the vesicle size for the present $A$. actinomycetemcomitans strains indeed was larger than the pores in the chosen filter. This renders unlikely the possibility that vesicles would have passed through the filter, which was further confirmed by the absence of vesicles in the filtrates. No literature was found about release of material from intact vesicles. Instead, vesicles are known to be considerably stable structures $[37,38]$ and therefore, the possibility that lysed vesicles would have been the source of free-soluble AaPAL may be low.

Yet another possibility was that $A$. actinomycetemcomitans cells had died and lysed in the inserts, so we continuously monitored the viability of the bacteria grown in the inserts. The fact the total bacterial numbers increased over time shows that viability was maintained in the experiments. However, despite the increased total numbers, lysis of dying bacteria in the growing A. actinomycetemcomitans population may have presented a source of AaPAL in the filtrate. Therefore, we, like others $[39,40]$, excluded the possibility of bacterial lysis by confirming the absence of a cytoplasmic marker in the same filtrate samples from which AaPAL was found.

Thus, neither vesicles passing through the filters nor cell death/lysis seemed to be the source of AaPAL in the filtrate samples. Further studies are needed to clarify the mechanism by which free-soluble AaPAL is released into extracellular space and how the release is regulated. Currently, it would be tempting to speculate that the mechanism involves activation of outer membrane phospholipase A [41-43]. By degrading phospholipids of the outer membrane, phospholipase A could liberate AaPAL along with 


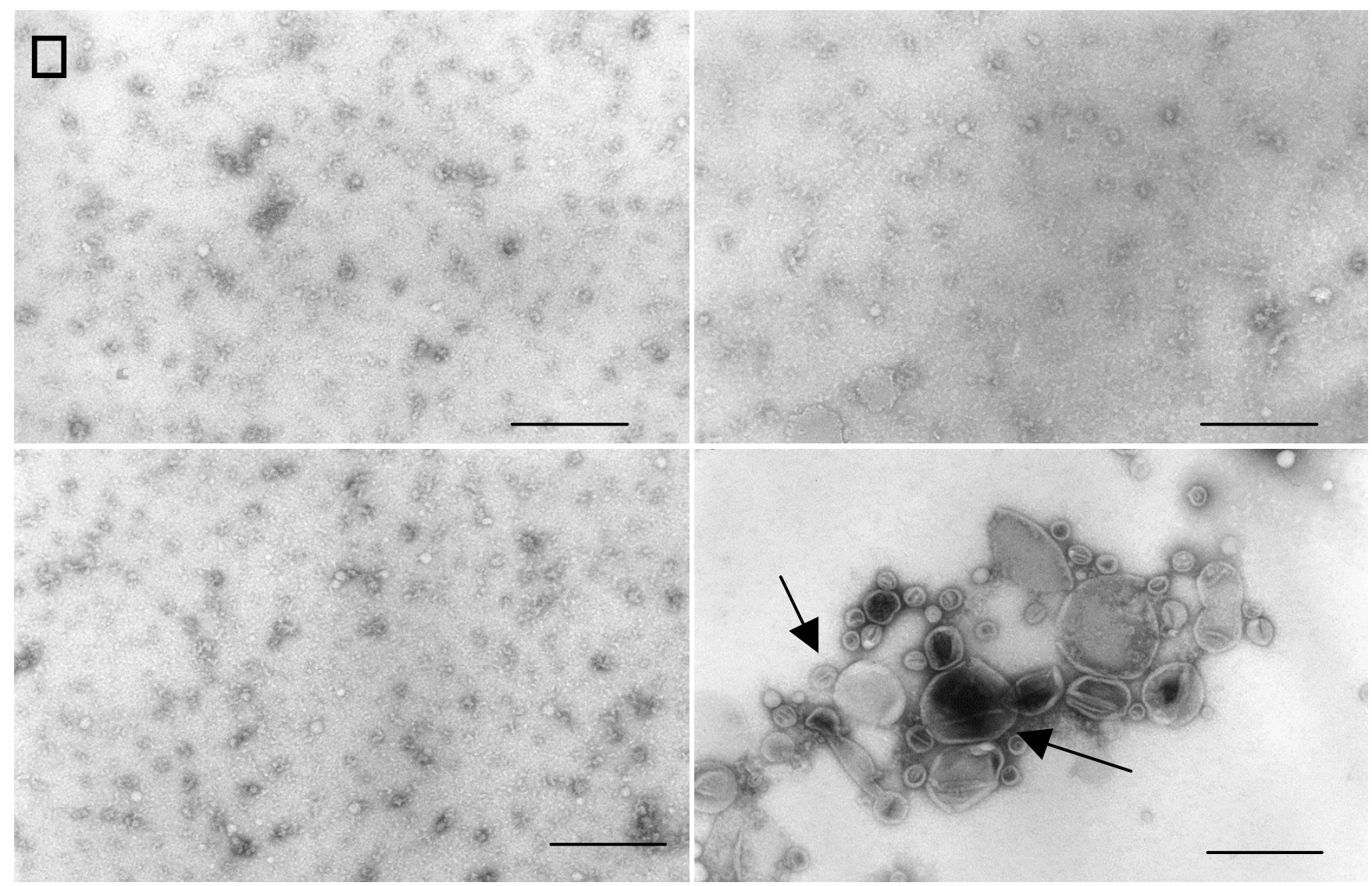

\section{Figure 8}

Electron micrographs of the vesicle preparations from filtrates. Filtrates from experiments studying in vitro AaPAL release into serum were subjected to vesicle preparation and subsequent electron microscopy. The filtrates were: $A$. actinomycetemcomitans D7SS at $8 \mathrm{~h}$ (Panel A), D7SS-p at $8 \mathrm{~h}$ (Panel B), No bacteria control at $2 \mathrm{~h}$ (Panel C). The vesicle preparation from A. actinomycetemcomitans D7SS whole cells (positive control) shows vesicles of different sizes indicated by arrows (Panel D). Bars; $0.2 \mu \mathrm{m}$.

other components of the outer membrane into the extracellular milieu. For other species, release of cell components, such as proteins, LPS and phospholipids has been reported following activation of phospholipase A, without an effect on growth or cell morphology [44]. Due to its strict regulation, phospholipase A activity does not lead to bacterial cell lysis $[41,45]$.

For the biological activity of the released free-soluble AaPAL it is crucial that it retains the lipid domain, because lipoprotein-mediated cytokine induction is solely attributed to the lipid domain [46]. Our results support the retention of the lipid part of AaPAL, since the immunoblot detection from the filtrate demonstrated a band of the same MW $(\approx 17 \mathrm{kDa})$ as that of purified AaPAL (without lipid domain, the amino acid sequence-based theoretical $\mathrm{MW}$ of AaPAL is $\approx 14 \mathrm{kDa}$ ). Therefore, the extracellularly released AaPAL seems to be neither proteolytically cleaved nor missing its lipid domain. The activity of free-soluble AaPAL may also be related to its association with other bacterial components. Our present study did not provide data to suggest an association but demonstrated co-release of AaPAL with LPS and other unidentified A. actinomycetemcomitans components. However, an association is possible, since previous studies have shown tight association between LPS and released E. coli PAL [8], as well as between extracellularly released OmpA, major lipoprotein, PAL and LPS $[23,31]$.

Since in this study we were unable to obtain the extracellularly released AaPAL in pure form and therefore did not know whether or not it was complexed with other bacterial components, we chose to study the immunostimulatory effect of purified AaPAL in an ex vivo model. Our results showed a dose-dependent enhancement in the production of IL-6, IL-8, and MIP- $1 \beta$ after an 8-h stimulation, using purified AaPAL. A search of the literature revealed no previous studies of cytokine production from whole blood by using AaPAL, or other lipoproteins or OMPs of this species. The only study on other species also 


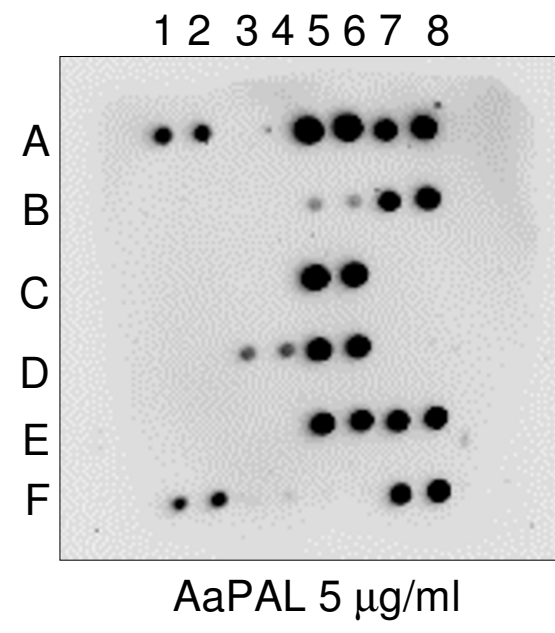

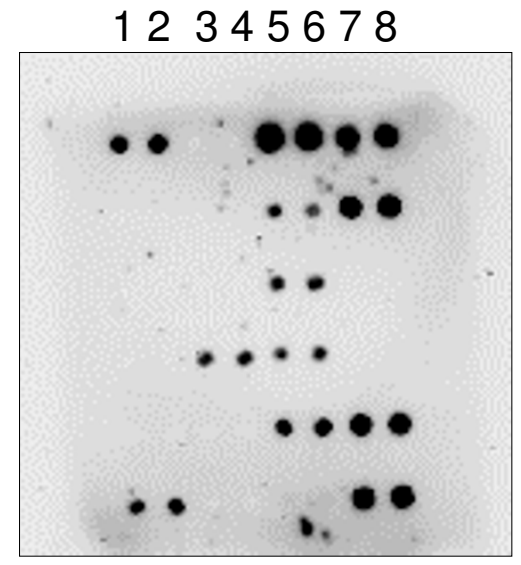

AaPAL $1 \mu \mathrm{g} / \mathrm{ml}$

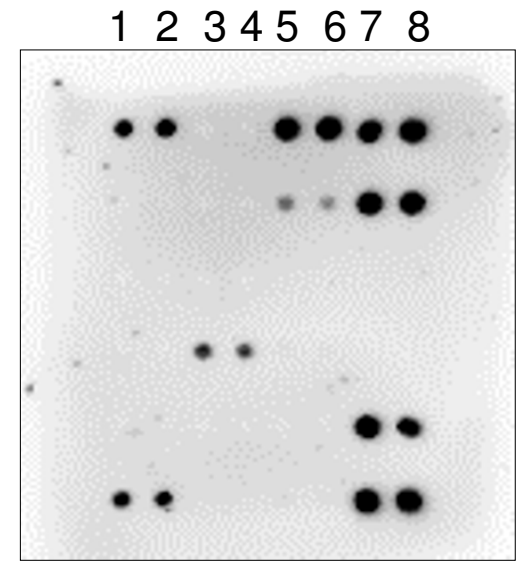

Control

\begin{tabular}{|ccccc|}
\hline & $\mathbf{1 2}$ & $\mathbf{3} \mathbf{4}$ & $\mathbf{5} \mathbf{6}$ & $\mathbf{7} \mathbf{8}$ \\
\hline A & Eotaxin & IP-10 & Rantes & pos \\
B & GM-CSF & TNF- $\alpha$ & Leptin & pos \\
C & IL-1 $\alpha$ & IL-3 & IL-6 & neg \\
D & IL-1 $\beta$ & IL-4 & IL-8 & neg \\
E & IL-10 & IL-17 & MIP1 $\beta$ & pos \\
F & IL-12 & MIP1 $\alpha$ & MIP-5 & pos \\
\hline
\end{tabular}

\section{Figure 9}

Cytokine induction of human whole blood by AaPAL. A cytokine antibody array was used to detect cytokines produced by human whole blood after stimulation with purified AaPAL (5 and I $\mu \mathrm{g} / \mathrm{ml}$ of blood) for $8 \mathrm{~h}$. Storage buffer of AaPAL served as the negative control. Abbreviations: pos $=$ positive, neg $=$ negative.

reported an increased IL- 6 production from blood after incubation with E. coli PAL [8]. In general, IL-6 and IL-8 are among the major cytokines produced by whole blood after stimulation with bacterial components [47-52]. IL-6 has a wide range of biological activities, among them proinflammatory properties and a role as the main stimulus for acute phase protein synthesis and release from liver in infection [53]. One of the two chemokines induced by AaPAL in our study, IL-8, a prototypic CXC-chemokine and classically known as a neutrophil chemoattractant, mediates monocyte trafficking and functions as a macrophage stimulator [54]. The other chemokine, MIP-1 $\beta$, a CC-subfamily chemokine, is a potent chemoattractant for monocytes and T cells [55]. Thus, even though we currently do not know the bioactivity of released free-soluble AaPAL, in purified form AaPAL has proinflammatory and prochemotactic properties that can lead to stimulation and differentiation of various cell types and further production of cytokines.

Our consistent results from RFLP of the A. actinomycetemcomitans pal gene and the immunoblot detection of the gene product indicate that the gene is conserved and the protein ubiquitously expressed in clonally diverse A. actinomycetemcomitans strains. This is in agreement with the intraspecies conservation of pal in other Pasteurellaceae members, such as Haemophilus influenzae [56]. The intraspecies conservation of AaPAL suggests that its bioactivity is comparable among different A. actinomycetemcomitans strains. The fact that AaPAL was expressed in a variety of different nutritional and atmospheric conditions may underscore its importance for the normal function of the bacterium. In addition, AaPAL was expressed during the exposure to serum and culture in anaerobic atmosphere. 
Since these conditions bear resemblance to those in pathologically deepened periodontal pockets, the results suggest that AaPAL is also expressed in vivo.

We included the pal-deficient mutant strains of A. actinomycetemcomitans primarily to corroborate our results from the immunoblot and other experiments. Comparisons of the phenotypic characteristics of the mutant and parent may, however, provide preliminary information about the role and function of AaPAL in A. actinomycetemcomitans cell physiology. We found that the mutants had decreased growth rate and filamentous cell morphology, differing partly from the pal-deficient mutant of H. ducreyi, which showed unchanged growth rate [14]. Although there were limitations in the present methods for estimating bacterial numbers, our results are consistent with previous reports demonstrating reduced growth rate of bacteria with mutations in tol-pal genes $[13,57,58]$. Moreover, the antimicrobial susceptibility of the pal-deficient A. actinomycetemcomitans mutant, D7SS-p, selectively changed. The susceptibility to erythromycin, but not to the $\beta$-lactams, increased. Previous studies have shown increased antibiotic susceptibility of strains with tol-pal gene mutations [59]. Additionally, mutations in genes encoding certain OMPs, such as ssc and envA of E. coli (encode 36- and 34-kDa OMPs, respectively), have resulted in hypersusceptibility to hydrophobic antibiotics, including erythromycin [60]. Our finding that the susceptibility of the pal-deficient A. actinomycetemcomitans mutant to the tested $\beta$-lactams did not increase may result from the inefficiency of the $\beta$-lactam antibiotics to kill slowly multiplying bacteria [61].

\section{Conclusion}

Our results suggest that live A. actinomycetemcomitans cells release AaPAL in free-soluble form independent of vesicles. The proinflammatory and prochemotactic properties of AaPAL may contribute to producing a long-term immune challenge in persistent A. actinomycetemcomitansassociated infections. The extracellular release of PAL is also of more general interest because bacterial lipoproteins are increasingly being recognized as playing an important role in bacterial pathogenicity $[7,14,62]$.

\section{Methods}

\section{Bacteria and culture conditions}

The test bacteria included 33 A. actinomycetemcomitans strains of 6 serotypes [63-65] and 15 genotypes $[66,67]$. A. actinomycetemcomitans strains were of oral $(\mathrm{N}=31)$ and non-oral $(\mathrm{N}=2)$ origin. Unless otherwise stated, strains were cultured on either supplemented blood agar plates [4], tryptic soy agar plates (TSA), or broth (TSB) (supplemented with $0.6 \%$ yeast extract, $0.8 \%$ glucose) (Difco, Sparks, MD, USA) and incubated in either $\mathrm{CO}_{2}$-enriched air $(5 \%)$ or anaerobic atmosphere $\left(85 \% \mathrm{~N}_{2}, 10 \% \mathrm{H}_{2}, 5 \%\right.$
$\mathrm{CO}_{2}$ ) at $37^{\circ} \mathrm{C}$ for $3 \mathrm{~d}$. For biofilm growth [27], the bacteria were cultured in TSB in a 24-well cell culture plate (Nunc ${ }^{\mathrm{TM}}$, Nunc, Denmark) and incubated in either $\mathrm{CO}_{2}{ }^{-}$ enriched air or anaerobic atmosphere, as detailed above, for $5 \mathrm{~d}$. $V$. cholerae strains BML24/pHA $7\left(\mathrm{crp}^{+}\right)$and BML24/pBR322 (crp-) (Wai, unpublished) were cultured in Luria Bertani broth at $37^{\circ} \mathrm{C}$ overnight with shaking.

\section{Production of anti-AaPAL peptide antiserum}

Antiserum was raised in rabbit against two synthetic peptides of AaPAL (N-terminal: 4-37 and C-terminal: 123136), as described earlier [3].

\section{SDS-PAGE and immunoblot}

Bacterial outer membrane fraction was extracted as previously described [4]. Bacteria suspended in PBS were used for whole cell protein preparation. SDS-PAGE and immunoblot were performed as previously described [4]. For immunoblots we used anti-AaPAL peptide antiserum [3], an antiserum against whole cells of A. actinomycetemcomitans serotype a [64], and $V$. cholerae cAMP receptor protein [68]. Unless specified otherwise, the antisera were used at final dilutions of 1:100 000, 1:1000, and 1:3000, respectively. Horseradish peroxidase-conjugated anti-rabbit secondary antibodies were used at a final dilution of 1:10000 or 1:20000. Immunoreactive bands were visualized using SuperSignal ${ }^{\circledast}$ (Pierce, Rockford, IL, USA).

\section{pal-deficient mutant strains}

D7SS-p, the pal-deficient mutant derivative of strain D7SS (spontaneous smooth-colony variant of wild-type D7S), was constructed by gene replacement technique as described earlier [69]. The pal::Spe allele of D7SS-p was transferred to the wild-type fimbriated strain D7S, using natural transformation [70], generating D7S-p. The presence of the pal::Spe allele in D7S-p was confirmed by PCR using the primers PAL-Sm 5'-CTTTCCCGGGACATAACGG and PAL-Hd 5'-GCTGAAAGCTTATAGTG TAAGAG. The abolished AaPAL expression in the pal-deficient mutants was confirmed by immunoblot using anti-AaPAL peptide antiserum.

\section{PCR-restriction fragment length polymorphism (PCR- RFLP) of the A. actinomycetemcomitans pal sequence} For RFLP, PCR amplicons generated by the primers PALSA 5'-GCTGGTTCTGTGGCTGTGT and PAL-MK 5'-ACTGCACGACGGTTTTTAGC were purified (QIAquick ${ }^{\circledR}$ Gel Extraction Kit, Qiagen GmbH, Helden, Germany) and digested with BspMI and DdeI (New England BioLabs, Beverly, MA, USA), respectively, prior to analysis on agarose $(1.8 \%)$ gel electrophoresis. 


\section{Phenotypic characterization of mutants}

Phenotypic characteristics, such as colony size and density, cell morphology, growth rate, and antibiotic susceptibility were studied as follows:

\section{Light microscopy}

$10-\mu$ inocula containing $10^{3}$ cells of strains D7SS, D7SSp, D7S, and D7S-p were cultured on supplemented blood agar and TSA plates as described above and observed under a stereomicroscope (Nikon SMZ800, Tokyo, Japan). The cell morphology was evaluated using phase contrast microscopy at $\times 1000$ magnification (Leica DMRBE).

\section{Scanning electron microscopy (SEM)}

The strains D7SS, D7SS-p, D7S, and D7S-p cultured on TSA plates were fixed (2.5\% glutaraldehyde in PBS; RT, 5 min) and prepared according to established methods. The cells were dehydrated using increasing concentrations of ethanol, and thereafter dried from liquid $\mathrm{CO}_{2}$ by the critical-point drying technique [71] using a Polaron E-3000 CPD apparatus (Polaron Equipment Ltd, Watford, UK). The cover slips with attached bacteria were mounted on aluminum stubs with silver dag (Agar Scientific Ltd, Stansted, UK) and coated (approximately $15 \mathrm{~nm}$ of carbon and gold) in an Edwards E12 Vacuum Coating Unit (Edwards High Vacuum Ltd, Crawley, UK). Bacterial cell morphology was examined in a Cambridge S360ixp scanning electron microscope run with a LaB6 electron emittor (Leica Cambridge Ltd, Cambridge, UK) and the micrographs were recorded from randomly selected areas with standardized magnifications.

\section{Growth rate}

For determining the growth rates for the strains D7SS and D7SS-p, log-phase cultures were used to inoculate TSB. The growth was measured as turbidity at $\mathrm{OD}_{600}$.

\section{Antibiotic susceptibility}

The D7SS and D7SS-p strains were grown in lawn cultures $\left(1 \times 10^{8} \mathrm{CFU} /\right.$ plate $)$ on TSA plates on which discs of erythromycin $(15 \mu \mathrm{g} /$ disc $)$, cefotaxime $(30 \mu \mathrm{g} /$ disc $)$, and penicillin (10 U/disc) (BD Biosciences, San Jose, CA, USA) were placed. The plates were incubated at $37^{\circ} \mathrm{C}$ in $\mathrm{CO}_{2^{-}}$ enriched air for $3 \mathrm{~d}$. Inhibition zones were measured in millimeters.

\section{Isolation of outer membrane vesicles}

Outer membrane vesicles were isolated as described previously [40] with some modifications. A. actinomycetemcomitans strains D7SS and D7SS-p were cultured on supplemented blood agar plates for 3 days as described above. Bacteria were harvested and suspended into sterile PBS and centrifuged at $5000 \times \mathrm{g}(10 \mathrm{~min}, \mathrm{RT})$ to pellet the bacteria. The supernatant was filtered $(0.22 \mu \mathrm{m}$; Milli- pore, Billerica, MA, USA) to remove any remaining intact bacterial cells. The filtrate was ultracentrifuged at 125000 $\times \mathrm{g}\left(3 \mathrm{~h}, 4^{\circ} \mathrm{C}\right)$ using a $70 \mathrm{Ti}$ rotor (Beckman Instruments Inc. Palo Alto, CA, USA). The obtained pellet was lyophilized and suspended in sterile PBS. The outer membrane vesicle preparations were examined by electron microscopy as described earlier [40]. Briefly, the vesicle samples were stained with $0.5 \%$ uranyl acetate and examined by a JEM 2000 ET electron micoscope (JEDL, Akishima, Tokyo, Japan) at $100 \mathrm{KV}$.

\section{Cell culture insert model for studying extracellular release of AaPAL in vitro}

Cell culture insert experiments were carried out using exposure to serum ( 2 and $8 \mathrm{~h}$ ) and culture in broth $(24 \mathrm{~h}$ ) as follows: A. actinomycetemcomitans cells $\left(1 \times 10^{9} \mathrm{CFU} /\right.$ $\mathrm{ml}$ ) were suspended in heat inactivated $50 \%$ fetal calf serum (FCS) (Invitrogen Gibco, Carlsbad, CA, USA) in PBS. The cell suspension was transferred into inserts (membrane pore size $0.02 \mu \mathrm{m}$ ), which were placed in cell culture wells (Nunc) containing FCS. The procedure for culturing in broth was similar to that for FCS, except that the wells contained TSB and the bacterial cells were suspended in TSB to a concentration of $1 \times 10^{8} \mathrm{CFU} / \mathrm{ml}$. Inserts containing serum or broth without bacteria served as negative controls.

For detection of released AaPAL, following incubation at $37^{\circ} \mathrm{C}$ in $\mathrm{CO}_{2}$-enriched air, $100 \mu \mathrm{l}$ samples, referred to as "filtrates" henceforth, were taken from serum (at 0, 2, and $8 \mathrm{~h}$ ) and broth (at 0 and $24 \mathrm{~h}$ ) from the wells outside the inserts. Samples from serum and broth filtrates, containing 10 and $30 \mu \mathrm{g}$ protein, respectively, were subjected to immunoblot analysis. The amount of AaPAL released into serum filtrate was quantified by densitometry (Quantity One $^{\circledR}$ software, Bio-Rad, Hercules, CA, USA) using purified AaPAL $(2,4,6$, and $8 \mathrm{ng})$ as a reference. As the intensities of AaPAL bands were very similar in all three independent experiments, data from only one experiment was chosen for densitometric quantification.

To monitor the viability of A. actinomycetemcomitans cells in serum and broth during incubation, $10-\mu$ l samples of the bacterial suspensions were taken from the inserts at the same time points as the samples were taken from the filtrates for immunoblot. Since bacterial cells might have sedimented to the bottom during incubation, the bacterial suspensions inside the inserts were pipetted in and out repeatedly 4-5 times to make the suspension homogeneous before taking out the samples for culture and viable counts. Appropriate serial dilutions of the samples were plated on supplemented blood agar plates and incubated at $37^{\circ} \mathrm{C}$ in $\mathrm{CO}_{2}$-enriched air for $3 \mathrm{~d}$. To exclude bacterial contamination of the serum or broth filtrates, $10-\mu \mathrm{l}$ samples were also taken and cultured on supplemented 
blood agar plates. Limulus assay (Cape Cod, E. Falmouth, MA, USA) was used for the detection of LPS in the filtrates.

To ensure that the integrity of the insert membrane remained intact (i.e., no leakage of bacterial cells) and that AaPAL found in the filtrate was not due to cell lysis in the insert, immunoblot was used to analyze the presence of a cytoplasmic marker protein, cAMP receptor protein, in the filtrates, as described above for the detection of AaPAL. For concentration, the filtrates were precipitated using ice-cold trichloroacetic acid (final concentration $10 \%)$.

To deliberately cause release of cytoplasmic proteins, $A$. actinomycetemcomitans D7SS cells $\left(2 \times 10^{9}\right.$ cells $\left./ \mathrm{ml}\right)$ were lysed using Lysing matrix E provided in the FastDNA SPIN Kit for Soil (BIO 101, Q-Biogen, Montreal, Canada) with Mini-BeadBeater-8 (BioSpec Products Inc., Bartlesville, OK, USA) at highest speed for $3 \mathrm{~min}$. The lysed cells were incubated in broth in the cell culture insert as described above. Unlysed cells were incubated similarly as a negative control. After $8 \mathrm{~h}$ incubation, filtrates collected from the wells were TCA-precipitated and the cAMP receptor protein was detected by immunoblotting as above.

To investigate whether outer membrane vesicles passed through the insert membrane filters in our experimental setup, serum filtrates were ultracentrifuged using the same procedure for sample preparation and electron microscopic examination as described above for the isolation of outer membrane vesicles.

\section{Cytokine induction from human whole blood by AaPAL}

AaPAL was purified by affinity chromatography as described previously [3]. Each microgram of purified AaPAL had LPS contamination of less than $5 \mathrm{pg}$, an amount which was shown not to contribute to AaPALinduced cytokine production [72]. AaPAL TranSignal human cytokine antibody arrays (Panomics, Redwood City, CA, USA) were used to profile cytokines produced by human whole blood. Blood sample from a healthy individual was drawn via venipuncture into heparin-containing tubes (BD Biosciences). Blood was immediately stimulated with AaPAL (final concentration 1 and $5 \mu \mathrm{g} / \mathrm{ml}$ blood; $37^{\circ} \mathrm{C}, 5 \% \mathrm{CO}_{2}, 8 \mathrm{~h}$ ), followed by centrifugation $(5000 \times \mathrm{g}, 5 \mathrm{~min})$ and cytokine analysis of the supernatants (5-fold dilutions) as instructed by the array manufacturer. Blood stimulated with AaPAL storage buffer served as a reference. Aliquots of blood were taken at $0 \mathrm{~h}$ and $8 \mathrm{~h}$ and plated on supplemented blood agar plates for bacterial contamination check. The experiment was repeated once.

\section{Statistical analysis}

Unless otherwise indicated all experiments were repeated thrice. Mann-Whitney $U$ test was used to determine the significance of the differences between the parental strain and the isogenic mutant in antibiotic susceptibilities and in the LPS amounts released into serum or broth. A Pvalue of less than 0.05 was regarded as statistically significant.

\section{Authors' contributions}

MK contributed to the study design, performed most laboratory work (developed the insert model, performed most bacterial cultures and outer membrane protein preparations, carried out antibiotic susceptibility tests, immunoblots, PCR-RFLP analyses, blood stimulations, cytokine assays, vesicle preparations, and microphotography), and contributed to SEM analyses, to all data analysis, interpretation, and reporting, as well as preparation of the manuscript.

RI participated in the study design, contributed to production of anti-AaPAL peptide antiserum and to AaPAL purification, PCR-RFLP and biofilm cultures and respective data analyses and interpretations.

KE participated in Limulus assays for determining LPS concentrations and respective data analyses and interpretations.

DZ helped in SDS-PAGE and immunoblot of whole cell protein preparations, bacterial cultures and growth curve experiments and respective data analyses.

JO constructed the D7S-p mutant and was involved in drafting the manuscript

SNW contributed to outer membrane vesicle preparation and electron microscopy, provided antibodies against cAMP receptor protein, and commented on the manuscript.

CC constructed the pal-deficient mutant D7SS-p and contributed to the design of genetic manipulations of A. actinomycetemcomitans needed for constructing the D7S-p, and commented on the manuscript

SA conceived of the study, contributed to insert model development and data analysis, interpretation, and reporting, and is the responsible author for study coordination and manuscript preparation.

\section{Acknowledgements}

We thank Mrs. Elisabeth Granström for excellent technical assistance. 
This work was supported by grants from the Swedish Medical Research Council No. 52I-2002-6520/S.A. and 2006-06X-|4747-04-3/S.A., and County Council of Västerbotten, Sweden/S.A.

\section{References}

I. Norskov-Lauritsen N, Kilian M: Reclassification of Actinobacillus actinomycetemcomitans, Haemophilus aphrophilus, Haemophilus paraphrophilus and Haemophilus segnis as Aggregatibacter actinomycetemcomitans gen. nov., comb. nov. Aggregatibacter aphrophilus comb. nov. and Aggregatibacter segnis comb. nov., and emended description of Aggregatibacter aphrophilus to include $V$ factor-dependent and $\mathbf{V}$ factor-independent isolates. Int J Syst Evol Microbiol 2006, 56(Pt 9):2135-2|46.

2. Socransky SS, Haffajee AD: The bacterial etiology of destructive periodontal disease: current concepts. J Periodontol 1992, 63(4 Suppl):322-33I

3. Ihalin R, Karched M, Eneslatt K, Asikainen S: Characterization of immunoaffinity purified peptidoglycan-associated lipoprotein of Actinobacillus actinomycetemcomitans. J Chromatogr B Analyt Technol Biomed Life Sci 2006, 83 I (I-2): I I6-I 25.

4. Paul-Satyaseela M, Karched M, Bian Z, Ihalin R, Boren T, Arnqvist A, Chen C, Asikainen S: Immunoproteomics of Actinobacillus actinomycetemcomitans outer-membrane proteins reveal a highly immunoreactive peptidoglycan-associated lipoprotein. I Med Microbiol 2006, 55(Pt 7):931-942.

5. Sturgis JN: Organisation and evolution of the tol-pal gene cluster. J Mol Microbiol Biotechnol 2001, 3(I): I I3-1 22.

6. Berenson CS, Murphy TF, Wrona CT, Sethi S: Outer membrane protein P6 of nontypeable Haemophilus influenzae is a potent and selective inducer of human macrophage proinflammatory cytokines. Infect Immun 2005, 73(5):2728-2735.

7. Hellman J, Roberts JD Jr., Tehan MM, Allaire JE, Warren HS: Bacterial peptidoglycan-associated lipoprotein is released into the bloodstream in gram-negative sepsis and causes inflammation and death in mice. J Biol Chem 2002, 277( I 6): | 4274-| 4280.

8. Liang MD, Bagchi A, Warren HS, Tehan MM, Trigilio JA, Beasley-Topliffe LK, Tesini BL, Lazzaroni JC, Fenton MJ, Hellman J: Bacterial peptidoglycan-associated lipoprotein: a naturally occurring toll-like receptor 2 agonist that is shed into serum and has synergy with lipopolysaccharide. J Infect Dis 2005, | 9 | (6):939-948

9. Zhu X, Bagchi A, Zhao H, Kirschning CJ, Hajiar RJ, Chao W, Hellman J, Schmidt U: Toll-like receptor 2 activation by bacterial peptidoglycan-associated lipoprotein activates cardiomyocyte inflammation and contractile dysfunction. Crit Care Med 2007 35(3):886-892.

10. Burnens A, Stucki U, Nicolet J, Frey J: Identification and characterization of an immunogenic outer membrane protein of Campylobacter jejuni. J Clin Microbiol I995, 33( I I):2826-2832.

II. Carbonetti NH, Artamonova GV, Andreasen C, Dudley E, Mays RM, Worthington ZE: Suppression of serum antibody responses by pertussis toxin after respiratory tract colonization by Bordetella pertussis and identification of an immunodominant lipoprotein. Infect Immun 2004, 72(6):3350-3358.

12. Yoon WS, Park SH, Park YK, Park SC, Sin JI, Kim MJ: Comparison of responses elicited by immunization with a Legionella species common lipoprotein delivered as naked DNA or recombinant protein. DNA Cell Biol 2002, 2 I(2):99-107.

13. Murphy TF, Kirkham C, Lesse AJ: Construction of a mutant and characterization of the role of the vaccine antigen P6 in outer membrane integrity of nontypeable Haemophilus influenzae. Infect Immun 2006, 74(9):5I69-5I76.

14. Fortney KR, Young RS, Bauer ME, Katz BP, Hood AF, Munson RS Jr., Spinola SM: Expression of peptidoglycan-associated lipoprotein is required for virulence in the human model of Haemophilus ducreyi infection. Infect Immun 2000, 68( I I ):644 I-6448.

15. Stathopoulos C, Hendrixson DR, Thanassi DG, Hultgren SJ, St Geme JW 3rd, Curtiss R 3rd: Secretion of virulence determinants by the general secretory pathway in gram-negative pathogens: an evolving story. Microbes Infect 2000, 2(9): 1061-1072.

16. Pukatzki S, Ma AT, Sturtevant D, Krastins B, Sarracino D, Nelson WC, Heidelberg JF, Mekalanos J]: Identification of a conserved bacterial protein secretion system in Vibrio cholerae using the Dictyostelium host model system. Proc Natl Acad Sci U S A 2006, I03(5): I528-1533.

17. Sandkvist M: Type II secretion and pathogenesis. Infect Immun 2001, 69(6):3523-3535.

18. Beveridge TJ: Structures of gram-negative cell walls and their derived membrane vesicles. I Bacteriol 1999, I 8 | ( I 6):4725-4733.

19. Kuehn MJ, Kesty NC: Bacterial outer membrane vesicles and the host-pathogen interaction. Genes Dev 2005, I 9(22):2645-2655.

20. Fujita Y, Yamaguchi K, Kamegaya T, Sato H, Semura K, Mutoh K, Kashimoto T, Ohori H, Mukai T: A novel mechanism of autolysis in Helicobacter pylori: possible involvement of peptidergic substances. Helicobacter 2005, I 0(6):567-576.

21. Aliprantis AO, Weiss DS, Radolf JD, Zychlinsky A: Release of Tolllike receptor-2-activating bacterial lipoproteins in Shigella flexneri culture supernatants. Infect Immun 200I, 69(10):6248-6255.

22. Freudenberg MA, Meier-Dieter U, Staehelin T, Galanos C: Analysis of LPS released from Salmonella abortus equi in human serum. Microb Pathog 1991, I 0(2):93-104.

23. Hellman J, Zanzot EM, Loiselle PM, Amato SF, Black KM, Ge Y, Kurnick JT, Warren HS: Antiserum against Escherichia coli J5 contains antibodies reactive with outer membrane proteins of heterologous gram-negative bacteria. J Infect Dis 1997, I 76(5): I 260- I 268.

24. Tesh VL, Duncan RL Jr., Morrison DC: The interaction of Escherichia coli with normal human serum: the kinetics of serum-mediated lipopolysaccharide release and its dissociation from bacterial killing. J Immunol I986, I 37(4): I 329-I335.

25. Zhang H, Niesel DW, Peterson JW, Klimpel GR: Lipoprotein release by bacteria: potential factor in bacterial pathogenesis. Infect Immun 1998, 66 (I I):5 I 96-520I.

26. Ricci V, Chiozzi V, Necchi V, Oldani A, Romano M, Solcia E, Ventura $U$ : Free-soluble and outer membrane vesicle-associated VacA from Helicobacter pylori: Two forms of release, a different activity. Biochem Biophys Res Commun 2005, 337(I): $173-178$.

27. Kaplan JB, Meyenhofer MF, Fine DH: Biofilm growth and detachment of Actinobacillus actinomycetemcomitans. I Bacteriol 2003, I 85(4): | 399-| 404.

28. Skare JT, Champion Cl, Mirzabekov TA, Shang ES, Blanco DR, Erdjument-Bromage H, Tempst P, Kagan BL, Miller JN, Lovett MA: Porin activity of the native and recombinant outer membrane protein Oms28 of Borrelia burgdorferi. I Bacteriol 1996 , I 78( 1 6):4909-49|8.

29. Vaughan TE, Skipp PJ, O'Connor CD, Hudson MJ, Vipond R, Elmore MJ, Gorringe AR: Proteomic analysis of Neisseria lactamica and Neisseria meningitidis outer membrane vesicle vaccine antigens. Vaccine 2006, 24(25):5277-5293.

30. Gophna U, Ideses D, Rosen R, Grundland A, Ron EZ: OmpA of a septicemic Escherichia coli O78--secretion and convergent evolution. Int J Med Microbiol 2004, 294(6):373-38I.

31. Hellman J, Loiselle PM, Tehan MM, Allaire JE, Boyle LA, Kurnick JT, Andrews DM, Sik Kim K, Warren HS: Outer membrane protein $A$, peptidoglycan-associated lipoprotein, and murein lipoprotein are released by Escherichia coli bacteria into serum. Infect Immun 2000, 68(5):2566-2572.

32. Hellman J, Loiselle PM, Zanzot EM, Allaire JE, Tehan MM, Boyle LA Kurnick JT, Warren HS: Release of gram-negative outer-membrane proteins into human serum and septic rat blood and their interactions with immunoglobulin in antiserum to Escherichia coli J5. J Infect Dis 2000, I 8 I (3): I 034- I 043.

33. Lee VT, Schneewind O: Protein secretion and the pathogenesis of bacterial infections. Genes Dev 200।, I 5( I 4): I725- I752.

34. Mayrand D, Grenier D: Biological activities of outer membrane vesicles. Can J Microbiol 1989, 35(6):607-613.

35. Smalley JW, Birss AJ, Shuttleworth CA: The degradation of type I collagen and human plasma fibronectin by the trypsin-like enzyme and extracellular membrane vesicles of Bacteroides gingivalis W50. Arch Oral Biol 1988, 33(5):323-329.

36. Kato S, Kowashi $Y$, Demuth DR: Outer membrane-like vesicles secreted by Actinobacillus actinomycetemcomitans are enriched in leukotoxin. Microb Pathog 2002, 32(I): I- I3. 
37. McBroom AJ, Johnson AP, Vemulapalli S, Kuehn MJ: Outer membrane vesicle production by Escherichia coli is independent of membrane instability. J Bacteriol 2006, I 88( I 5):5385-5392.

38. Renelli M, Matias V, Lo RY, Beveridge TJ: DNA-containing membrane vesicles of Pseudomonas aeruginosa PAOI and their genetic transformation potential. Microbiology 2004, I50(Pt 7):216I-2I69.

39. Hoekstra D, van der Laan JW, de Leij L, Witholt B: Release of outer membrane fragments from normally growing Escherichia coli. Biochim Biophys Acta 1 976, 455(3):889-899.

40. Wai SN, Lindmark B, Soderblom T, Takade A, Westermark M, Oscarsson J, Jass J, Richter-Dahlfors A, Mizunoe Y, Uhlin BE: Vesiclemediated export and assembly of pore-forming oligomers of the enterobacterial ClyA cytotoxin. Cell 2003, I I 5(I):25-35

4I. Dekker N: Outer-membrane phospholipase A: known struc ture, unknown biological function. Mol Microbiol 2000, 35(4):7| I-7I7.

42. Istivan TS, Coloe PJ: Phospholipase A in Gram-negative bacteria and its role in pathogenesis. Microbiology 2006, I52(Pt 5): $1263-1274$

43. Sitkiewicz I, Stockbauer KE, Musser JM: Secreted bacterial phospholipase A2 enzymes: better living through phospholipolysis. Trends Microbiol 2007, I 5(2):63-69.

44. Audet A, Nantel G, Proulx P: Phospholipase A activity in growing Escherichia coli cells. Biochim Biophys Acta 1974 348(3):334-343.

45. Snijder HJ, Dijkstra BW: Bacterial phospholipase A: structure and function of an integral membrane phospholipase. Biochim Biophys Acta 2000, I488( I-2):91-101.

46. Aliprantis AO, Yang RB, Mark MR, Suggett S, Devaux B, Radolf JD, Klimpel GR, Godowski P, Zychlinsky A: Cell activation and apoptosis by bacterial lipoproteins through toll-like receptor-2. Science 1999, 285(5428):736-739.

47. Araya AV, Pavez V, Perez C, Gonzalez F, Columbo A, Aguirre A, Schiattino I, Aguillon JC: Ex vivo lipopolysaccharide (LPS)-induced TNF-alpha, IL-Ibeta, IL-6 and PGE2 secretion in whole blood from Type I diabetes mellitus patients with or without aggressive periodontitis. Eur Cytokine Netw 2003, I4(3): I28-I33.

48. Frieling JT, Mulder JA, Hendriks T, Curfs JH, van der Linden CJ, Sauerwein RW: Differential induction of pro- and anti-inflammatory cytokines in whole blood by bacteria: effects of antibiotic treatment. Antimicrob Agents Chemother 1997, 4I(7): |439-| 443.

49. Heinzelmann $M$, Bosshart $H$ : Heparin binds to lipopolysaccharide (LPS)-binding protein, facilitates the transfer of LPS to CDI4, and enhances LPS-induced activation of peripheral blood monocytes. J Immunol 2005, I 74(4):2280-2287.

50. Jagger MP, Huo Z, Riches PG: Inflammatory cytokine (inter leukin 6 and tumour necrosis factor alpha) release in a human whole blood system in response to Streptococcus pneumoniae serotype 14 and its capsular polysaccharide. Clin Exp Immunol 2002, I30(3):467-474.

51. Matera G, Liberto MC, Quirino A, Barreca GS, Lamberti AG, lannone M, Mancuso E, Palma E, Cufari FA, Rotiroti D, Foca A: Bartonella quintana lipopolysaccharide effects on leukocytes, CXC chemokines and apoptosis: a study on the human whole blood and a rat model. Int Immunopharmacol 2003, 3(6):853-864.

52. Mohrschladt MF, Weverling-Rijnsburger AW, de Man FH, Stoeken DJ, Sturk A, Smelt AH, Westendorp RG: Hyperlipoproteinemia affects cytokine production in whole blood samples ex vivo. The influence of lipid-lowering therapy. Atherosclerosis 2000 , I 48(2):4I3-4I9.

53. Curfs JH, Meis JF, Hoogkamp-Korstanje JA: A primer on cytokines: sources, receptors, effects, and inducers. Clin Microbiol Rev 1997, I 0(4):742-780.

54. Boisvert WA: Modulation of atherogenesis by chemokines. Trends Cardiovasc Med 2004, 14(4): 161-165.

55. Menten $\mathrm{P}$, Wuyts $\mathrm{A}$, Van Damme J: Macrophage inflammatory protein-I. Cytokine Growth Factor Rev 2002, I3(6):455-48I.

56. Nelson MB, Munson RS Jr., Apicella MA, Sikkema DJ, Molleston JP, Murphy TF: Molecular conservation of the P6 outer membrane protein among strains of Haemophilus influenzae: analysis of antigenic determinants, gene sequences, and restriction fragment length polymorphisms. Infect Immun |99|, 59(8):2658-2663.
57. Llamas MA, Ramos JL, Rodriguez-Herva J]: Mutations in each of the tol genes of Pseudomonas putida reveal that they are critical for maintenance of outer membrane stability. J Bacteriol 2000, I 82(I 7):4764-4772.

58. Rodriguez-Herva JJ, Ramos JL: Characterization of an OprL null mutant of Pseudomonas putida. I Bacteriol 1996, I 78( I 9):5836-5840.

59. Cascales E, Bernadac A, Gavioli M, Lazzaroni JC, Lloubes R: Pal lipoprotein of Escherichia coli plays a major role in outer membrane integrity. J Bacteriol 2002, I 84(3):754-759.

60. Vaara M: Antibiotic-supersusceptible mutants of Escherichia coli and Salmonella typhimurium. Antimicrob Agents Chemother I993, 37( I I ):2255-2260.

6I. Tuomanen E, Cozens R, Tosch W, Zak O, Tomasz A: The rate of killing of Escherichia coli by beta-lactam antibiotics is strictly proportional to the rate of bacterial growth. J Gen Microbiol 1986, I 32(5): | 297-| 304

62. Adu-Bobie J, Lupetti P, Brunelli B, Granoff D, Norais N, Ferrari G, Grandi G, Rappuoli R, Pizza M: GNA33 of Neisseria meningitidis is a lipoprotein required for cell separation, membrane architecture, and virulence. Infect Immun 2004 72(4):1914-1919.

63. Kaplan JB, Perry MB, MacLean LL, Furgang D, Wilson ME, Fine DH: Structural and genetic analyses of $O$ polysaccharide from Actinobacillus actinomycetemcomitans serotype f. Infect Immun 200I, 69(9):5375-5384.

64. Saarela M, Asikainen S, Alaluusua S, Pyhala L, Lai CH, Jousimies-Somer $\mathrm{H}$ : Frequency and stability of mono- or poly-infection by Actinobacillus actinomycetemcomitans serotypes $\mathbf{a}, \mathbf{b}, \mathbf{c}, \mathbf{d}$ or e. Oral Microbiol Immunol 1992, 7(5):277-279.

65. Suzuki N, Nakano Y, Yoshida Y, Ikeda D, Koga T: Identification of Actinobacillus actinomycetemcomitans serotypes by multiplex PCR. J Clin Microbiol 200I, 39(5):2002-2005.

66. Asikainen $\mathrm{S}$, Chen $\mathrm{C}$, Slots ]: Actinobacillus actinomycetemcomitans genotypes in relation to serotypes and periodontal status. Oral Microbiol Immunol I995, I0(2):65-68.

67. Dogan B, Saarela M, Asikainen S: Genotyping of Actinobacillus actinomycetemcomitans serotype $d$ isolates based on polymerase chain reaction. Oral Microbiol Immunol 1999 | 4(6):387-390.

68. Kouokam JC, Wai SN, Fallman M, Dobrindt U, Hacker J, Uhlin BE: Active cytotoxic necrotizing factor I associated with outer membrane vesicles from uropathogenic Escherichia coli. Infect Immun 2006, 74(4):2022-2030.

69. Wang $Y$, Chen C: Mutation analysis of the flp operon in Actinobacillus actinomycetemcomitans. Gene 2005, 35 I:6 I-7I

70. Wang Y, Goodman SD, Redfield RJ, Chen C: Natural transformation and DNA uptake signal sequences in Actinobacillus actinomycetemcomitans . J Bacteriol 2002, I 84( I 3):3442-3449.

7I. Anderson TF: Techniques for the preservation of threedimensional structure in preparing specimens for the electron microscope. Volume 13. Trans NY Acad Sci; I95 I:I30-I34.

72. Ihalin R Eneslätt, K., and Asikainen, S.: Peptidoglycan-associated lipoprotein of Actinobacillus actinomycetemcomitans induces TLR2 mediated production of proinflammatory cytokines from macrophages: September 6-9; Paris. 2006.

Publish with Bio Med Central and every scientist can read your work free of charge

"BioMed Central will be the most significant development for disseminating the results of biomedical research in our lifetime. "

Sir Paul Nurse, Cancer Research UK

Your research papers will be:

- available free of charge to the entire biomedical community

- peer reviewed and published immediately upon acceptance

- cited in PubMed and archived on PubMed Centra

- yours - you keep the copyright 